\title{
Harapan dan Realitas Implementasi Regulasi Jaminan Produk Halal Di Indonesia
}

\author{
Arif Rachman Eka Permata \\ Magister Ilmu Ekonomi, Universitas Trunojoyo Madura \\ arifrachman2594@gmail.com
}

DOI: https://doi.org/10.21107/dinar.v5i1.5128

\begin{abstract}
Abstrak
Industri halal menjadi sektor potensial untuk dikembangkan di era digitalisasi ekonomi sekarang ini, khususnya di Indonesia. Berlakunya UU RI No.33 Tabun 2014 tentang jaminan produk halal membuktikan bahwa pemerintah mulai serius dalam mengembangkan industri tersebut. Selain melalui regulasi, pemerintah menjalankan program-program sosialisasi dan pendampingan serta pemberian fasilitas pada pelaku industri tersebut dalam memperbaiki kualitas kelembagan agar perkembangannya bisa maksimal. Hal tersebut dilakukan dengan harapan agar industri halal di Indonesia bisa berkembang, sebingga memiliki dampak positif terbadap perekonomian di Indonesia. Harapan tersebut tentunya harus ditunjang dengan realitas di masyarakat apakah memang memungkinkan dijadikan sebagai sektor yang potensial sebagai salah satu tumpuan perekonomian di Indonesia.

Untuk metode penelitian, artikel ini menggunakan pendekatan kualitatif dengan jenis penelitian studi literatur. Metode pengumpulan data yang digunakan dalam penelitian ini menggunakan teknik triangulasi teori (theory triangulation). Metode analisis data yaitu teknik analisis data deskriptif kualitatif.

Hasil dari artikel ini memberikan diskripsi bahwa harapan dikembangkannya industri balal ialab untuk. memaksimalkan potensi masyarakat muslim yang begitu besarr di dunia mengingat banyak orang muslim atau non muslim yang sadar akan produk halal sangat baik untuk kehidupan, potensi ini harus dikelola melalui pengembangan produk halal yang ditunjang dengan adanya regulasi produk halal. Selanjutnya tentunya harapannya ialah sebagai media dalam mengatasi masalah sosial ekonomi, sehingga termujudnya kesejabteraan. Untuk realitas, industri halal sedang dalam proses pengembangan dan pembenahan melalui regulasi dan program yang terarah.
\end{abstract}

Kata Kunci: harapan, realitas, regulasi jaminan produk halal. 


\section{Pendahuluan}

Kemiskinan masih menjadi permasalahan mendasar yang dihadapi oleh bangsa Indonesia (Azhar, et. al.: 2017, 16). Penyebab kemiskinan dapat dilihat dari beberapa kondisi sosial yang ada. Berdasarkan Kakwani dalam Ahmed, et. al. (2017) dilihat sebagai orang miskin tidak hanya dalam perampasan material (diukur berdasarkan pendapatan atau konsumsi) tetapi juga aspek-aspek yang berbeda kehidupan seperti pengangguran, kesehatan yang buruk, kurangnya pendidikan, kerentanan, ketidakberdayaan atau sosial pengecualian. Sehingga Di Indonesia, melalui Perpres Nomor 18 tahun 2007, sasaran pembangunan ekonomi tahunan Indonesia diarahkan untuk mendorong pertumbuhan ekonomi dalam rangka memperluas lapangan pekerjaan dan mengurangi tingkat kemiskinan (Fathurrahman, 2012). Oleh karena itu, selanjutnya kebijakan pemerintah tersebut tentunya harus diiringi dengan pengembangan sektor startegis, salah satunya yaitu industri halal.

Pemerintah mengeluarkan undang-undang untuk memaksimalkan pengembangan industri halal, melalui UU No 3 Tahun 2014 tentang jaminan produk halal diharapkan industri ini akan berkembang dengan signifikan. Dalam UU ini, penyelenggara JPH adalah Badan Penyelenggara Jaminan Produk Halal (BPJPH) bekerjasama dengan LPH (Lembaga Pemeriksa Halal) dan MUI sebagai penerbit fatwa halal. BPJPH berada di bawah dan bertanggungjawab kepada menteri. Selain itu, UU ini memberikan kemudahan bagi pengusaha mikro mendapatkan bantuan dari APBN dan APBD (Nidya Waras Syekti, 2014).

Beberapa ketentuan UU No 33 tahun 2014 tentang Jaminan Produk Halal antara lain pasal 4 yang menyatakan bahwa produk yang masuk, beredar dan diperdagangkan di Indonesia wajib bersertifikat halal. Selanjutnya Pasal 5 ayat (1) UU JPH mengamanatkan dibentuknya Badan penyelenggara Jaminan Produk Halal (BPJPH) yang menurut ayat (5) ketentuan mengenai fungsi, tugas, dan susunan organisasi BPJPH diatur dalam Peraturan Presiden (Zumar Amirudin, 2006). Lima tahun setelah disahkan undang-undang ini semua produk yang beredar di masyarakat wajib mencantumkan sertifikat halal pada kemasannya dan sebaliknya apabila produk terdiri dari bahan yang tidak halal berdasarkan Pasal 29 ayat (2) pelaku usaha wajib mencantum pada kemasan produk tanda tidak halal, misalnya gambar babi (Syafrida, 2017: 165).

Disampaikan oleh Kepala Pusat Registrasi Dan Sertifikasi Halal Badan Penyelenggara Jaminan Produk Halal pada september 2017, bahwa dasar adanya penerapan UU tersebut ialah melihat potensi jumlah konsumen muslim di Indonesia ataupun dunia yang cukup besar, produk yang beredar di masyarakat belum terjamin kehalalannya sehingga seorang yang sebetulnya paham tentang halâlan thayyiban pada suatu yang dikonsumsi akan ragu dalam membeli dan mengkonsumsi, dampaknya permintaan akan menurun. Selanjutnya banyaknya kasus-kasus yang ditemukan dalam masalah kehalalan produk. Proses dalam penataan dan menjaga sesuatu yang akan dikonsumsi oleh seseorang menjadi begitu penting, dengan 
adanya UU tersebut sangat membantu dalam perubahan paradigma masyarakat tentang pentingnya mengkonsumsi sebuat produk yang halâlanthayyiban.

Ma'ruf Amin dalam Panji Adam (2017: 150) menyatakan bahwa makanan halal-haram bukan hanya masalah umatmuslim saja, melainkan juga berkaitan dengan masyarakat luas pada umumnya. Hal ini sejalan dengan ketentuan syariat Islam yang menegaskan bahwa tujuan dan tugas hidup manusia yang pertama dan utama di muka bumi ini adalah untuk beribadah dan mengabdi kepada Allah. Lantas bagaimana mungkin ibadah dan doa seseorang dapat diterima oleh Allah, jika makanan dan minumannya tidak suci dan baik. Karena itu, agar ibadah dan doa diterima oleh Allah, maka harus berusaha semaksimal mungkin agar makanan dan minuman yang dikonsumsi terjamin halâl dan thayyib-nya, sebagai bagian dari syarat diterimanya ibadah dan doa.

Hal ini terbutkti dengan kata-kata halâlan thayyiban (Q.S 2: 168). Karena tidak semua makanan yang halal akan menjadi thayyib bagi konsumennya. Misalnya penderita penyakit diabetes, dalam kondisi sakit dengan kadar gula yang tinggi dalam tubuhnya namun tetap saja dia mengonsumsi gula. Hal ini tentu saja membahayakan kesehatan konsumen gula tersebut, walaupun gula tersebut halâl untuk dikonsumsi namun tidak baik/thayyib bagi konsumen tersebut. Melihat hal diatas tentunya ada potensi yang bisa dikembangkan dalam industri halal ini, dengan adanya UU No 33 Tahun 2014 tentang jaminan produk halal secara implementasi akan mendorong peningkatan konsumen akan produk halal. Maka dari itu menarik untuk dikaji tentang harapan dan realitas bagaimana penerapan regulasi pemerintah tentang jaminan produk halal di Indonesia.

\section{Tinjauan Pustaka}

\section{Harapan (Expected Feeling)}

Harapan atau asa adalah bentuk dasar dari kepercayaan akan sesuatu yang diinginkan akan didapatkan atau suatu kejadian akan bebuah kebaikan di waktu yang akan datang. Pada umumnya harapan berbentuk abstrak, tidak tampak, tetapi diyakini bahkan terkadang, dibatin dan dijadikan sugesti agar terwujud. Namun adakalanya harapan tertumpu pada seseorang atau sesuatu. Pada praktiknya banyak orang mencoba menjadikan harapannya menjadi nyata dengan cara berdoa atau berusaha. Beberapa pendapat menyatakan bahwa esensi harapan berbeda dengan "berpikir positif" yang merupakan salah satu cara terapi/ proses sistematis dalam psikologi untuk menangkal "pikiran negatif" atau "berpikir pesimis".

Teori Harapan atau Teori Ekspektansi (Expectancy Theory of motivation) dikemukakan oleh Victor H. Vroom pada tahun 1964. Terdapat tiga asumsi pokok Vroom dalam teori harapan. Asumsi-asumsi tersebut adalah sebagai berikut :

Setiap individu percaya bahwa bila ia berprilaku dengan cara tertentu, ia akan memperoleh hal tertentu. Ini disebut sebuah harapan hasil (outcome expectancy) sebagai 
penilaian subjektif seseorang atas kemungkinan bahwa suatu hasil tertentu akan muncul dari tindakan orang tersebut. Setiap hasil mempunyai nilai, atau daya tarik bagi orang tertentu. Ini disebut valensi (valence) sebagai nilai yang orang berikan kepada suatu hasil yang diharapkan.

Setiap hasil berkaitan dengan suatu persepsi mengenai seberapa sulit mencapai hasil tersebut. Ini disebut harapan usaha (effort expectancy) sebagai kemungkinan bahwa usaha seseorang akan menghasilkan pencapaian suatu tujuan tertentu. Teori ini menyatakan bahwa kekuatan yang memotivasi seseorang untuk bekerja giat dalam mengerjakan pekerjaannya tergantung dari hubungan timbal balik antara apa yang diinginkan dan dibutuhkan dari hasil pekerjaan itu.

Vroom dalam Koontz (1990) mengemukakan bahwa orang-orang akan termotivasi untuk melakukan hal-hal tertentu guna mencapai tujuan apabila mereka yakin bahwa tindakan mereka akan mengarah pada pencapaian tujuan tersebut. Teori harapan ini didasarkan atas: Pertama harapan (Expectancy) adalah suatu kesempatan yang diberikan akan terjadi karena perilaku atau suatu penilaian bahwa kemungkinan sebuah upaya akan menyebabkan kinerja yang diharapkan. Kedua nilai (Valence) adalah akibat dari perilaku tertentu mempunyai nilai/martabat tertentu (daya/nilai motivasi) bagi setiap individu yang bersangkutan. Dengan kata lain, Valence merupakan hasil dari seberapa jauh seseorang menginginkan imbalan/ signifikansi yang dikaitkan oleh individu tentang hasil yang diharapkan. Ketiga pertautan (Instrumentality) adalah persepsi dari individu bahwa hasil tingkat pertama ekspektansi merupakan sesuatu yang ada dalam diri individu yang terjadi karena adanya keinginan untuk mencapai hasil sesuai dengan tujuan atau keyakinan bahwa kinerja akan mengakibatkan penghargaan.

Ekspektansi merupakan salah satu penggerak yang mendasari seseorang untuk melakukan suatu tindakan. Karena dengan adanya usaha yang keras tersebut, maka hasil yang didapat akan sesuai dengan tujuan. Dalam teori ini disebutkan bahwa seseorang akan memaksimalkan sesuatu yang menguntungkan dan meminimalkan sesuatu yang merugikan bagi pencapaian tujuan akhirnya. Expectancy Theory berasumsi bahwa seseorang mempunyai keinginan untuk menghasilkan suatu karya pada waktu tertentu tergantung pada tujuantujuan khusus orang yang bersangkutan dan juga pemahaman seseorang tersebut tentang nilai suatu prestasi kerja sebagai alat untuk mencapai tujuan tersebut.

Ini adalah kepuasan yang diharapkan dan tidak aktual bahwa seorang karyawan mengharapkan untuk menerima setelah mencapai tujuan. Harapan adalah keyakinan bahwa upaya yang lebih baik akan menghasilkan kinerja yang lebih baik. Harapan dipengaruhi oleh faktor-faktor seperti kepemilikan keterampilan yang sesuai untuk melakukan pekerjaan, ketersediaan sumber daya yang tepat, ketersediaan informasi penting dan mendapatkan dukungan yang diperlukan untuk menyelesaikan pekerjaan. 


\section{Realitas}

Realitas atau kenyataan, dalam bahasa sehari-hari berarti "hal yang nyata; yang benarbenar ada". Dalam pengertiannya yang sempit dalam filsafat barat, ada tingkat-tingkat dalam sifat dan konsep tentang realitas. Tingkat-tingkat ini mencakup, dari yang paling subyektif hingga yang paling ketat: realitas fenomenologis, kebenaran, fakta, dan aksioma.

Realitas pada tingkat yang lebih luas dan lebih subyektif, pengalaman-pengalaman pribadi, rasa ingin tahu, pencarian, dan selektivitas terlibat dalam penafsiran pribadi tentang suatu kejadian membentuk realitas sebagaimana yang dilihat oleh satu dan hanya satu orang saja dan oleh karena itu disebut fenomenologis. Bentuk realitas ini mungkin umum bagi orang lain juga, pada kadang-kadang juga bisa menjadi sangat unik bagi diri sendiri sehingga tidak pernah dialami atau disetujui oleh orang lain. Banyak dari pengalaman yang dianggap spiritual seperti ini terjadi pada realitas tingkat ini. Dari perspektif fenomenologis, realitas adalah sesuatu yang secara fenomenal nyata sementara non-realitas dianggap tidak ada. Persepsi individual dapat didasarkan pada kepribadian seorang individu, fokus, dan gaya atribusinya, sehingga membuat hanya dialah yang melihat apa yang ingin dilihat atau dipercayainya sebagai kebenaran.

\section{Regulasi Jaminan Produk Halal}

Dasar regulasi jaminan produk halal adalah Undang-Undang No 33 Tahun 2014 tentang Jaminan Produk Halal. Undang-Undang Nomor 33 tahun 2014 tentang Jaminan Produk Halal didalamnya mengatur tentang:

1) Jaminan ketersediaan Produk Halal, ditetapkan bahan produk yang dinyatakan halal, baik bahan yang berasal dari bahan baku hewan, tumbuhan, mikroba, maupun bahan yang dihasilkan melalui proses kimiawai, proses biologi, atau proses rekayasa genetik. Di samping itu, ditentukan pula PPH yang merupakan rangkaian kegiatan untuk menjamin kehalalan Produk yang mencakup penyediaan bahan, pengolahan, penyimpanan, pengemasan, pendistribusian, penjualan, dan penyajian Produk.

2) Undang-Undang ini mengatur hak dan kewajiban Pelaku Usaha dengan memberikan pengecualian terhadap Pelaku Usaha yang memproduksi Produk dari Bahan yang berasal dari Bahan yang diharamkan dengan kewajiban mencantumkan secara tegas keterangan tidak halal pada kemasan Produk atau pada bagian tertentu dari Produk yang mudah dilihat, dibaca, tidak mudah terhapus, dan merupakan bagian yang tidak terpisahkan dari Produk.

3) Dalam rangka memberikan pelayanan publik, Pemerintah bertanggung jawab dalam menyelenggarakan JPH yang pelaksanaannya dilakukan oleh BPJPH. Dalam menjalankan wewenangnya, BPJH bekerja sama dengan kementerian dan/atau lembaga terkait, MUI, dan LPH. 
4) Tata cara memperoleh Sertifikat Halal diawali dengan pengajuan permohonan Sertifikat Halal oleh Pelaku Usaha kepada BPJPH. Selanjutnya, BPJPH melakukan pemeriksaan kelengkapan dokumen. Pemeriksaan dan/atau pengujian kehalalan Produk dilakukan oleh LPH. LPH tersebut harus memperoleh akreditasi dari BPJH yang bekerjasama dengan MUI. Penetapan kehalalan Produk dilakukan oleh MUI melalui sidang fatwa halal MUI dalam bentuk keputusan Penetapan Halal Produk yang ditandatangani oleh MUI. BPJPH menerbitkan Sertifikat Halal berdasarkan keputusan Penetapan Halal Produk dari MUI tersebut.

5) Biaya sertifikasi halal dibebankan kepada Pelaku Usaha yang mengajukan permohonan Sertifikat Halal. Dalam rangka memperlancar pelaksanaan penyelenggaraan JPH, Undang- Undang ini memberikan peran bagi pihak lain seperti Pemerintah melalui anggaran pendapatan dan belanja negara, pemerintah daerah melalui anggaran pendapatan dan belanja daerah, perusahaan, lembaga sosial, lembaga keagamaan, asosiasi, dan komunitas untuk memfasilitasi biaya sertifikasi halal bagi pelaku usaha mikro dan kecil. Dalam rangka menjamin pelaksanaan penyelenggaraan JPH, BPJPH melakukan pengawasan terhadap LPH; masa berlaku Sertifikat Halal; kehalalan Produk; pencantuman Label Halal; pencantuman keterangan tidak halal; pemisahan lokasi, tempat dan alat pengolahan, penyimpanan, pengemasan, pendistribusian, penjualan, serta penyajian antara Produk Halal dan tidak halal; keberadaan Penyelia Halal; dan/atau kegiatan lain yang berkaitan dengan JPH.

6) Untuk menjamin penegakan hukum terhadap pelanggaran Undang-Undang ini, ditetapkan sanksi administratif dan sanksi pidana.

\section{Metode Penelitian}

\section{Jenis Penelitian}

Jenis penelitian dalam penelitian ini adalah kualitatif dengan pendekatan studi literatur dengan sumber data yaitu data sekunder yang diperoleh dari penelitian-penelitian terdahulu, dan sumber referensi lainnya. Studi literatur adalah cara yang dipakai untuk menghimpun data-data atau sumber-sumber yang berhubungan dengan topik yang diangkat dalam suatu penelitian yang didapat dari berbagai sumber, jurnal, buku dokumentasi, internet dan pustaka.Penelitian ini mencoba menggambarkan tentang harapan dan realitas yang terjadi di Indonesia tentang penerapan/ implementasi adanya regulasi jaminan produk halal.

\section{Jenis Data}

Jenis data dalam penelitian ini menggunakan data sekunder. Data sekunder adalah sumber data yang tidak langsung memberikan data kepada pengumpul data (Sugiono, 2008: 402). Data sekunder ini merupakan data yang sifatnya mendukung keperluan data primer 
seperti buku-buku, penelitian-penelitian sebelunya dan berbagai sumber bacaan yang berkaitan dengan regulasi jaminan produk halal ataupun industri halal.

\section{Metode Pengumpulan Data}

Metode pengumpulan data yang digunakan dalam penelitian ini menggunakan teknik triangulasi teori (theory triangulation). Data atau informasi dari satu pihak diperiksa kebenarannya dengan cara memperoleh informasi dari sumber lain (Abdullah dan Saebani, 2014: 73). Tujuannya adalah membandingkan informasi tentang hal yang sama yang diperoleh dari berbagai referensi dan literatur agar ada jaminan tingkat kepercayaannya.

\section{Metode Analisis Data}

Metode analisis data yaitu teknik analisis data deskriptif kualitatif yaitu dengan datadata yang diperoleh dari tinjauan literatur serta website terkait disusun menjadi sebuah faktafakta yang aktual untuk kemudian dilakukan pembahasan.

\section{Pembahasan}

\section{Harapan Implementasi Regulasi Jaminan Produk Halal di Indonesia}

Menurut Muhamad Sadi Ismail dalam Panji Adam (2017: 158) doktrin balal thayib (halal danbaik/bergizi) sangat perlu untukdiinformasikan secara efektif danoperasional kepada masyarakat, disertai dengan tercukupinya sarana prasarana. Salah satu sarana penting untuk mengawal doktrin halal dimaksud adalah hadirnya pranata hukum yang mapan,sentral, humanis, progresif, akomodatif,dan tidak diskriminatif, yakni UndangUndang Jaminan Produk Halal. Secara jelas dalam hal ini UU merupakan solusi dalam mempercepat pertumbuhan industri halal. Ketika paradigma masyarakat telah terbentuk tentang pentingnya halal thayib maka implementasi UU dikatakan mulai berhasil dan akan mempengaruhi perkembangan sub sektor lain di sektor industri halal.

Selanjutnya, harapan tentang implementasi regulasi jaminan produk halal didasari oleh optimalisasi pemanfaatan potensi besar yang dimili oleh pasar produk halal, secara jelas hal tersebut telah disampaikan oleh Kepala Pusat Registrasi Dan Sertifikasi Halal Badan Penyelenggara Jaminan Produk Halal pada september 2017 (State of The Global Islamic Economy 2013, Thomson Reuters) meliputi:

1) Pertumbuhan permintaan produk halal dunia $9,5 \%$ dari 2 trilliun USD (2013) menjadi 3,7 triliun USD tahun 2019.

2) Jumlah penduduk dunia th 2013 adalah 7.021.836.029 \pm 1,57 milyar beragama Islam.

3) Di Asia Tenggara, pemeluk agama Islam $>250$ juta.

4) Kesadaran gaya hidup halal meningkat.

5) Konsumsi Muslim global tumbuh 1.626 miliar USD (2018) sekitar $17,4 \%$ dari total konsumsi dunia. 
6) Indonesia konsumen terbesar produk halal \pm 197 miliar USD, Turki (100 miliar USD), Pakistan (93 miliar USD ) dan Mesir (88 miliar USD).

7) Kewajiban pemerintah mengeluarkan Sertifikat halal, secara umum sertifikasi halal adalah fatwa MUI secara tertulis menyatakan kehalalansuatu produk sesuai dengan syariat Islam. Pemberian sertifikat halal pada pangan,obat-obatan dan kosmetika untuk melindungi konsumen muslim terhadap produkyang tidak halal.

Sertifikat halal merupakan hak konsumen muslim yang harus mendapat perlindungan dari negara. Sertifikat halal tidak hanya memberi manfaat perlindungan hukum hak-hak konsumen muslim terhadap produk yang tidak halal, tapi juga meningkatka nnilai jual produk pelaku usaha, karena konsumen tidak akan ragu lagi untuk membeli produk yang diperdagangkan pelaku usaha. Logo sertifikat halalmemberikan kepastian hukum kepada konsumen muslim bahwa produk tersebuthalal sesuai syariat Islam.

\section{Realita Implementasi Regulasi Jaminan Produk Halal di Indonesia}

Regulasi jaminan produk halal secara khususnya melahirkan bentuk nyata dalam perwujudan implementasinya, salah satunya ialah sertifikat halal, sertifikat tersebut didapat melalui proses sertifikasi. Realita yang ada di Indonesia, sertifikasi muncul disebabkan karena motivasi kesadaran akan produk halal sudah menjadi bagian darikebutuhan kehidupan masyarakat yang mayoritas muslim, sehingga sangat mudah untukmenemukan produk halal di Indonesia. Bahkan lebih mudah untuk mendapatkan yanghalal dari pada yang haram. Namun di tengah-tengah melimpahnya produk halal, tidak jarang muncul produk halal, terutama yang dihasilkan oleh pabrik moderen. Masyarakat tidak mudah mengenali halal haramnya. Maka orientasi sertifkasi halal di Indonesiadidominasi oleh motivasi untuk melindungi masyarakat muslim sendiri, dan ini sudah diimplementasikan.

Sertifikasi halal yang oleh Majelis Ulama Indonesia sebenarnya untuk memberikan perlindungan hukum dan kepastian hukum bagi umat Islam dalam mengkonsumsi produk pangan maupun kosmetika yang berasal dari produsen. Majelis Ulama Indonesia sendiri bekerjasama LPPOM berupaya semaksimal mungkin untuk menetapkan sebuah produk itu halal atau tidak dengan melakukan penelitian terhadap bahan baku, bahan tambahan, tempat pengolahan bahkan transportasi yang digunakan untuk mengantar produk makanan, tempat penjualan,tempat pengolahan, clean dari babi (Sheilla Chairunnisyah, 2017)

Memang awalnya tidak murni karena hal tersebut namun secara jelas sertifikasi halal di Indonesia pada awalnya merupakan gerakan civil society. Namun dalam perkembangan terakhir Indonesia mengalami pergeseran. Jika selama ini sertifkasi halal ditangani oleh LPPOM MUI yang merupakan lembaga swadaya masyarakat, sejak lahirnya UU Jaminan Produk Halal, 


\section{Aliar}

Eurnal \& konomi \& Qeuangan @slam

https://journal.trunojoyo.ac.id/dinar/index

DOI: https://doi.org/10.21107/dinar
Dinar. Vol 6, No 2: Agustus 2019. 1-10

ISSN: 2460-9889 (Cetak)

ISSN: 2580-3565 (Online)

penanganan sertifkasi menjadi wewenang negara melalui BPJPH yang merupakan lembaga negara.

MUI memang masih memiliki kewenangan untuk menetapkan halal dan haram. Tetapi proses formalnya, baik pemeriksaan saintifiknya maupun dikeluarkannya sertifkat menjadi wewenang BPJPH. Meskipun sampai saat ini belum terealisasi penuh, namun pada saatnya akan terwujud. Sertifikat halal memang membawa manfaat bagi mereka kinerja bisnis dalam hal pandangan Islam, kontribusi sosial, modal finansial, dan manusia modal. Sertifikasi halal adalah motivasi untuk mendapatkan manfaat agama, memberikan kepuasan kepada pelanggan lebih banyak peluang kerja dan menghindari masalah sosial. Dalam modal finansial, ia berfungsi sebagai internal sumber daya untuk meningkatkan penjualan dan memengaruhi keputusan pembelian pelanggan. Untuk sumber daya manusia, sertifikat halal dapat memberikan motivasi kerja dan peningkatan kualitas SDM (Asnidar Hanim Yusuf, 2017)

Secara kesimpulan jika membahas tentang keseluruhan regulasi, dapat dijelaskan sekilas bahwa implementasi regulasi halal di Indonesia tidak hanya fokus ke UU No 33 Tahun 2014, maka implementasi regulasi yang bisa diidentifikasi sampai saat ini ialah:

a. UU No. 33 Tentang Jaminan Produk Halal ditandatangi tahun2014

b. Kewajiban sertifikasi Halal Mandatori di mulai tahun 2019

c. 3 tahun setelah UU No. 33 thn 2014, Badan PenyelenggaraJaminan Produk Halal $(\mathrm{BPJPH})$ dibentuk dibawah MenteriAgama RI

d. 2019 Sertifikasi Halal dilaksanakan oleh BPJPH, LPH dan MUIuntuk Fatwa Halal

e. BPJPH di didirikan tanggal 11 Oktober 2017

\section{Kesimpulan}

Kesimpulan dari artikel ini memberikan diskripsi bahwa harapan dikembangkannya industri halal ialah untuk memaksimalkan potensi masyarakat muslim yang begitu besar di dunia. Banyak orang muslim atau non muslim yang sadar akan produk halal sangat baik untuk kehidupan, potensi ini harus dikelola melalui pengembangan produk halal yang ditunjang dengan adanya regulasi produk halal. Selanjutnya tentunya harapannya ialah sebagai media dalam mengatasi masalah sosial ekonomi, sehingga terwujudnya kesejahteraan. Untuk realitas, industri halal sedang dalam proses pengembangan dan pembenahan melalui regulasi dan program yang terarah.

\section{Daftar Pustaka}

Abdullah, Boedi, Beni Ahad Saebani. (2014). Metode Penelitian Ekonomi Islam (Muamalah), Bandung: CV Pustaka Setia. 


\section{Minar}

Adam, Panji. Kedudukan Sertifikasi Halal Dalam Sistem Hukum Nasional Sebagai Upaya Perlindungan Konsumen Dalam Hukum Islam, Jurnal Amwaluna, Vol 1 No 1 Januari 2017.

Aminuddin, Muh. Zumar, Sertifikasi Produk Halal: Studi Perbandingan Indonesia Dan Thailand, Jurnal Shahih Vol. 1 Tahun 2016

Azhar, Aziz Harry, et. al. (2017). Zakat dan Pemberdayaan, Surabaya: Airlangga University Press.

Chairunisyah, Sheilla. Peran Majelis Ulama Indonesia Dalam Menerbitkan Sertifikat Halal Pada Makanan Dan Kosmetik, Jurnal Edutech Vol 3 No 2 Tahun 2017

Fathurrahman, Ayief . Kebijakan Fiskal Indonesia Dalam Perspektif Ekonomi Islam: Studi Kasuh Dalam Mengentaskan Kemiskinan, Jurnal Ekonomi dan Studi Pembangunan, Volume 13, Nomor 1, April 2012.

https://id.wikipedia.org/wiki/Harapan diakses pada tanggal 20 Februari 2019 https://id.wikipedia.org/wiki/Kenyataan diakses pada tanggal 21 Februari 2019

Jaringan Dokumentasi dan Informasi Hukum Badan Standardisasi Nasional National Standardization Agency of Indonesia http://jdih.bsn.go.id/produk/detail/?id=15\&jns=2 diakses pada tanggal 21 Februari 2019

Sayekti, Nidya Waras. Jaminan Produk Halal Dalam Perspektif Kelembagaan, Jurnal Ekonomi Dan Kebijakan Publik, Vol. 5 No.2 Desember 2014

Sugiyono, (2008). Metode Penelitian Kunatitatif Kualitatif dan R\&D. Bandung Alfabeta.

Syafrida, Sertifikat Halal Pada Produk Makanan Dan Minuman Memberi Perlindungan Dan Kepastian Hukum Hak-Hak Konsumen Muslim, Jurnal Adil Vol 7 No 7 Tahun 2017

Yusuf, Asnidar Hanim Dkk. The Role Of Halal Certification In Business Performance In Selangor: A Study On Kopitiams, Jurnal Fakulty Of Economics Nd Muamalat Universiti Sains Islam Malaysia, 2017. 